\title{
The decreased of Streptococcus mutans growth after topical application of phosphopeptide amorphous calcium phosphate paste
}

\author{
Tika Faradina Araf*), Meirina Gartika*, Warta Dewi** \\ *Department of Pedodontics Faculty of Dentistry Universitas Padjadjaran, Bandung \\ **Department of Oral Biology Faculty of Dentistry Universitas Padjadjaran, Bandung
}

\section{ABSTRACT}

Casein Phosphopeptide-Amorphous Calcium Phosphate (CPP-ACP) paste is a topical application substance that consisted from a series of milk derivative peptide as a result of phosphorylation and has an antibacterial activity. The objective of this research was to find out the difference of Streptococcus mutans growth before and after CPP-ACP paste given topically to child teeth. The method of the research was quasi experiment. Research samples were 10 students of MI Al Falah Islamic Boarding School, Jatinangor, West Jawa Indonesia and collected with purposive sampling technique. This research used dental plaque from child teeth before and after applicated by CPP-ACP paste. Plaque was cultivated in selective media Tryptone Yeast Cystein Sucrose Bacitracin (TYCSB) with repeated twice. Streptococcus mutans colony in TYCSB were counted by Stuart colony counter and statistically analyzed based on paired t-test. The results showed the average of Streptococcus mutans growth before applicated CPP-ACP paste was 57.05, whereas after applicated CPP-ACP paste for 1 days was 9.4; for 3 days was 2.85; and for 14 days was 1.7 colony. The research concluded that there was a the decrease of Streptococcus mutans growth in isolate plaque after CPP-ACP paste topically given to child teeth.

Key words: Streptococcus mutans growth, casein phosphopeptide-amorphous calcium phosphate, dental plaque

\section{ABSTRAK}

Pasta Casein Phosphopeptide-Amorphous Calcium Phosphate (CPP-ACP) adalah bahan aplikasi topikal yang terdiri dari serangkaian peptida susu turunan sebagai hasil dari fosforilasi dan memiliki aktivitas antibakteri. Tujuan penelitian ini adalah untuk mengetahui perbedaan jumlah pertumbuhan Streptococcus mutans sebelum dan sesudah CPP-ACP pasta diberikan secara topikal untuk gigi anak. Metode penelitian adalah eksperimen semu. Sampel penelitian adalah 10 siswa MI Pondok Pesantren Al Falah Jatinangor yang dikumpulkan dengan teknik purposive sampling. Penelitian ini menggunakan plak gigi anak sebelum dan sesudah aplikasi pasta CPP-ACP. Plak dibiakkan pada media selektif Ragi Tryptone Sukrosa Sistein Bacitracin (TYCSB) dengan diulang dua kali. Koloni Streptococcus mutans di TYCSB dihitung oleh counter colony Stuart dan hasilnya dianalisis dengan uji statistik paired t-test. Hasil penelitian menunjukkan rata-rata jumlah pertumbuhan Streptococcus mutans sebelum diaplikasikan

\footnotetext{
*)Correspondence author: Tika Faradina Araf, Department of Pedodontic Faculty of Dentistry Universitas Padjadjaran
} Jl. Sekeloa Selatan No. 1 Bandung, West Java-Indonesia, Tel./Fax: +6222-2504985/2532805 
pasta CPP-ACP adalah 57,05, sedangkan setelah diaplikasikan CPP-ACP pasta untuk 1 hari adalah 9,4, selama 3 hari adalah 2,85, dan untuk 14 hari adalah 1,7 koloni. Penelitian ini menyimpulkan bahwa ada perbedaan jumlah pertumbuhan Streptococcus mutans pada isolat plak sebelum dan sesudah CPP-ACP paste diberikan secara topikal untuk gigi anak. Pertumbuhan koloni Streptococcus mutans berkurang setelah aplikasi secara topikal CPP-APP pada gigi anak.

Kata kunci: Jumlah pertumbuhan Streptokokus mutans, casein phosphopeptide-amorph phosphate calsium, plak gigi

\section{INTRODUCTION}

Oral and dental health issues are indeed important. This proved by the result of Household Health Survey (SKRT) in 2001 that oral and dental complained $60 \%$ of Indonesian. ${ }^{1}$ The effort to improve the oral and dental health can be done through plaque control. ${ }^{2}$ Plaque control is a measure to remove and prevent plaque deposit on the teeth and gum surfaces therefore it prevents and inhibits the periodontal diseases and also caries which cause reduced oral health level commonly found among the society. ${ }^{3,4}$

Dental caries is a chronical disease commonly found in children. This condition caused deciduous teeth to premature loss, which subsequently impaired the dental and jaw development. ${ }^{5}$ Based on the SKRT year 2004 it showed that dental caries prevalence in Indonesia is about $90.05 \%{ }^{1}$

Bacteria is an important factor in dental plaque formation and caries etiology also the periodontal disease. ${ }^{6}$ Streptococcus mutans is a bacteria capable of inducing caries and most isolated from dental plaque. ${ }^{3}$ Streptococcus mutans in the oral cavity can be found since a tooth erupted. This bacteria required teeth to form a stabilized colony in the oral cavity. ${ }^{7}$

Streptococcus mutans produced extracellular polysaccharide that would provide attachment, aggregation, and increased bacteria colony in an acquired pellicle, therefore dental plaque formed on dental surfaces. ${ }^{3,6}$ Streptococcus mutans is an acidogen plaque which produces excessive acid. Increased acid production had reduced the $\mathrm{pH}$ level thus demineralization of dental enamel occur and subsequently dental caries. ${ }^{8}$

Currently material used to inhibit the bacterial attachment is Casein Phosphopeptide Paste-Amorphic Calcium Phosphate (CPP-ACP). Reynolds and colleagues from University of
Melbourne at early 1980 induced a study about casein as a major protein from milk that possessed anti-cariogenic characteristic. Milk contained of casein, calcium, phosphate, and lipid possessed anti-cariogenic characteristic. ${ }^{9}$

CPP-ACP prepared commercially in a paste form which used topically, contained in toothpastes, mouthwashes, and chewing gums. CPP-ACP inihibits the bacterial growth inside the plaque. ${ }^{9}$ CPP-ACP bonds with saliva pellicle in vitro. This bond inhibits the Streptococcus mutans and Streptococcus sobrinus attachment. ${ }^{10}$ The result of the Reynolds et al. ${ }^{11}$ study of CPP-ACP in mouthwash and used for 5 days increased the calcium and phosphate inside the dental plaque thus inhibited the enamel demineralization. While used with chewing gums and lozenges which contained CPP-ACP for 14 days increased the enamel remineralization. ${ }^{12,13}$

This study objectives were to count the amount of Streptococcus mutans in the plaque isolate before and after application of CPP-ACP paste topically in children teeth, in order to find any significance of growth amount of Streptococcus mutans before and after application of CPP-ACP paste topically in children teeth.

\section{METHODS}

This was a quasi experimental study to find any significance or difference of Streptococcus mutans from plaque isolate before and after CPP-ACP paste application topically in children teeth. The population of this study was students of MI Al Falah Islamic Boarding School, Cileles, Jatinangor, Sumedang which met criterias, such as aged 6-12 years old; good general health; no systemic disease; no prostheses or orthodontic appliances; if there were any dental restoration it should be well adapted (no overhang, underfilled, 
or overfilled); no crowded teeth; good oral health; no caries nor white spot on the examined teeth; and cooperative.

The sample of this study was 10 children from the MI Al Falah Islamic Boarding School Cileles, Jatinangor, Sumedang which obtained by the purposive sampling technique based on the criterias of population and agreed to follow the study processes.

Materials used in this study were Casein Phosphopeptide Paste-Amorphous Calcium Phosphate (CPP-ACP), aquadest, sucrose bulyon solution and culture medium used was the selective agar media Tryptone Yeast Cystein Sucrose Bacitracin (TYCSB). The test bacteria was Streptococcus mutans.

This study processes were as follow: Preliminary study was examined the oral and dental health condition from subjects of this study based on the criterias of population. Then, explanation regarding the examination to the teacher and students which selected as a subject of this study. Parents asked to fill in the informed consent, and finally application of CPP-ACP paste.

Application of CPP-ACP paste daily for 14 days initiated at day-0 up to day-13. Operator applied the CPP-ACP paste to the subjects, as instructed as follow: prior to application of CPPACP paste, the tooth surface was brushed using appropriate technique. Subsequently it dried from saliva using cotton roll or cotton pellet. The CPP-ACP paste applied with sterilized cotton bud throughout the teeth surface. For three minutes it should be inside the mouth, not to be spit upon nor swallowed. The subject should not eat for 30 minutes after the CPP-ACP application. Subjects should follow and obeyed the instructions from examiner initiated at day-0 up to day- 13 .

Isolate collected prior to CPP-ACP paste application would be used as control. Subsequently isolate collected after the CPP-ACP paste applied for 1, 3, and 14 days. Isolate in form of supragingival plaque from lingual surface of lower first molar teeth.

Subjects rinsed their mouth with water to clean their mouth out of food debris, it was suggested distilled water as a mouthrinse, then the tooth surface isolated using the sterilized tampon to prevent saliva contamination. Plaque weight collected for every examination was $0.1 \mathrm{mg}$. One gram of plaque contains $2 \times 10^{11}$ bacterias. ${ }^{14}$ Which means that every $0.1 \mathrm{mg}$ of plaque contained $2 \times 10^{10}$ bacterias. The amount of Streptococcus mutans in dental plaque was about $0-50 \% .{ }^{15}$ Plaque collected using steril excavator. Prior to use the excavator for collection of plaque, its weight scaled using the Bosch analytic scale. After plaque collection, the excavator weight was re-scaled. The difference amount of scaled excavator was the plaque weight. Subsequently the plaque suspended into sucrose bulyon and straightly diluted twice, so that the concentration would be 1:10,1:100.

The first diluted tube, $0.1 \mathrm{mg}$ of plaque inserted into the sterilized test tube contained $1 \mathrm{ml}$ of sucrose bulyon and homogenized. After homogenous plaque and sucrose bulyon, taken 0.1 $\mathrm{ml}$ of the first suspension and inserted into 0.9 $\mathrm{ml}$ of sucrose bulyon in the second test tube and also been homogenized, then it would had been diluted for 1:100.

Every $0.1 \mathrm{ml}$ of the suspension of the last dilution shed using a sterilized pippette onto two agar medium of TYCSB as a repetition in order to achieve more accurate result, and subsequently spreaded evenly using oese. Then all of the cultured medium stored into anaerobic lid completed with gas generating kit and palladium catalyzer. Gas generating kit opened by cutting its edge of wrap. After opened inserted $10 \mathrm{ml}$ of distilled water using a beaker glass. Then the anaerobic lid incubated at $37^{\circ} \mathrm{C}$ for $3 \times 24$ hours.

Streptococcus mutans colony grew on the selective medium of TYCSB should gave characteristic as figure resembled cauliflower, white colored, irregular circumference, clear boundaries, shiny, and attached firmly on the medium surface. ${ }^{16}$ Bacterial colony suspected as Streptococcus mutans prepared with Gram coloration and observed under the light microscope. Streptococcus mutans in microsopic observation would be identified as round bacteria, arranged particularly with chain formation and positive Gram.

Colony of Streptococcus mutans counted. After micrograph observation which met the test bacteria characteristic subsequently the Streptococcus mutans grew on the TYCSB medium 
been counted using the bacteria colony count device.

Dental plaque is a soft deposit yellowish white colored, thin layer attached on tooth surfaces and would not detached upon gargle and also colored while applied the disclosing solution. Casein Phosphopeptide-Amorphous Calcium Phospate in paste form contained five flavors of melon, mint, strawberry, vanilla, tutty-fruity and prepared in tube. Streptococcus mutans in selective medium of TYCSB gave characteristic such as cauliflower, white colored, irregular border, clear circumference, shined, and tightly attached onto the medium. While in microscopic observation it was identified as rounded form bacteria, arranged particularly in chain formation, and purple colored. The paste applied topically on teeth surfaces.

\section{RESULTS}

Cultured Streptococcus mutans result in selective medium of TYCSB after being incubated for $3 \times 24$ hours in temperature $37^{\circ} \mathrm{C}$ obligate anaerobically would be a colony with characteristics such as resembled cauliflower, white colored, irregular circumference, clear boundaries, shiny, and attached firmly on the medium surface as seen in Figure 3. Gram coloration on the colony would resulted round form bacterias, arranged particularly in chain formation, Gram positive as in Figure 3.

Counted result of colony on TYCSB medium showed a difference between the mean of plaque isolate Streptococcus mutans growth amount before and after application of CPP-ACP paste on children teeth surfaces for 1,3 , and 14 days as seen on Table 1.

Mean value of Streptococcus mutans colony growth each timed $10^{2}$. The result on Diagram 1 showed that the mean value of plaque isolate Streptococcus mutans growth amount before CPP-ACP paste application topically on childreen teeth as much as 57.05 ; which means that every $0.1 \mathrm{ml}$ of prepared content contained $57.05 \times 10^{2}$ bacterias, while the mean value of Streptococcus mutans after CPP-ACP paste application for 1 day as much as 9.4 which means every $0.1 \mathrm{ml}$ of prepared content contained $9.4 \times 10^{2}$ bacterias, 3 days after CPP-ACP application returned to

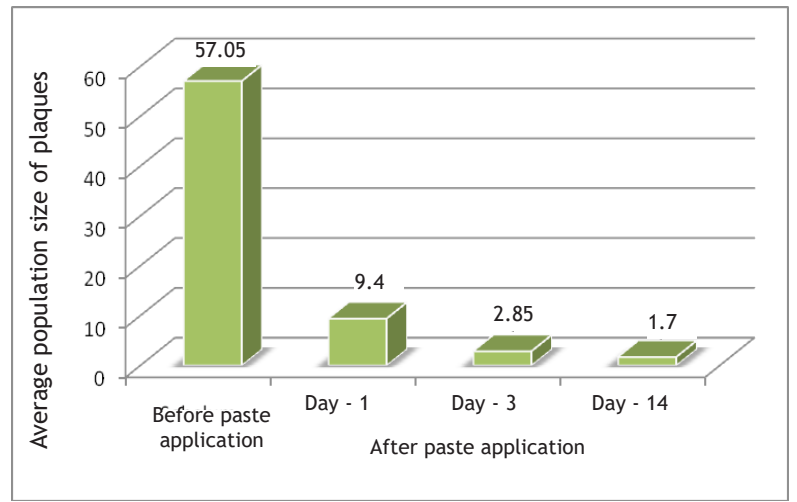

Graphic 1. Comparation of mean values of plaque isolate Streptococcus mutans growth amount before and after CPP-ACP paste application on children teeth.

2.85 which means that every $0.1 \mathrm{ml}$ of prepared content contained $2.85 \times 10^{2}$ bacterias, and 14 days after daily CPP-ACP application returned 1.7 which means in every $0.1 \mathrm{ml}$ of prepared content contained $1.7 \times 10^{2}$ bacterias. The comparation of mean values of Streptococcus mutans growth amount showed in Graphic 1.

Based on Graphic 1 decreased mean value of plaque isolate Streptococcus mutans growth could be seen after application of CPP-ACP paste topically on children teeth from day-1 up to day14. The mean of Streptococcus mutans colony growth after CPP-ACP paste application for 1 day decreased for 47.65 with average of $83.52 \%$; after 3 days of CPP-ACP paste application it decreased 54.2 with average percentage of $95 \%$; and after 14 consecutive days of CPP-ACP paste application it decreased 55.35 with average of $97.02 \%$. Figure 3 showed that plaque isolate Streptococcus mutans growth amount on selective medium of TYCSB after CPP-ACP paste application topically on children teeth for 1,3 , and 14 days were decreased after CPP-ACP paste application.

The statistic test in order to find difference of plaque isolate Streptococcus mutans growth amount before and after CPP-ACP paste application on children teeth using the coupled $t$ test with a $=0.05$ could be seen in Table 2 . That means there was difference which significant statistically between plaque isolate Streptococcus mutans growth before and after CPP-ACP paste application on children teeth, in form of decreased value of Streptococcus mutans growth after CPP-ACP paste application for 1,3 , and 14 days. 


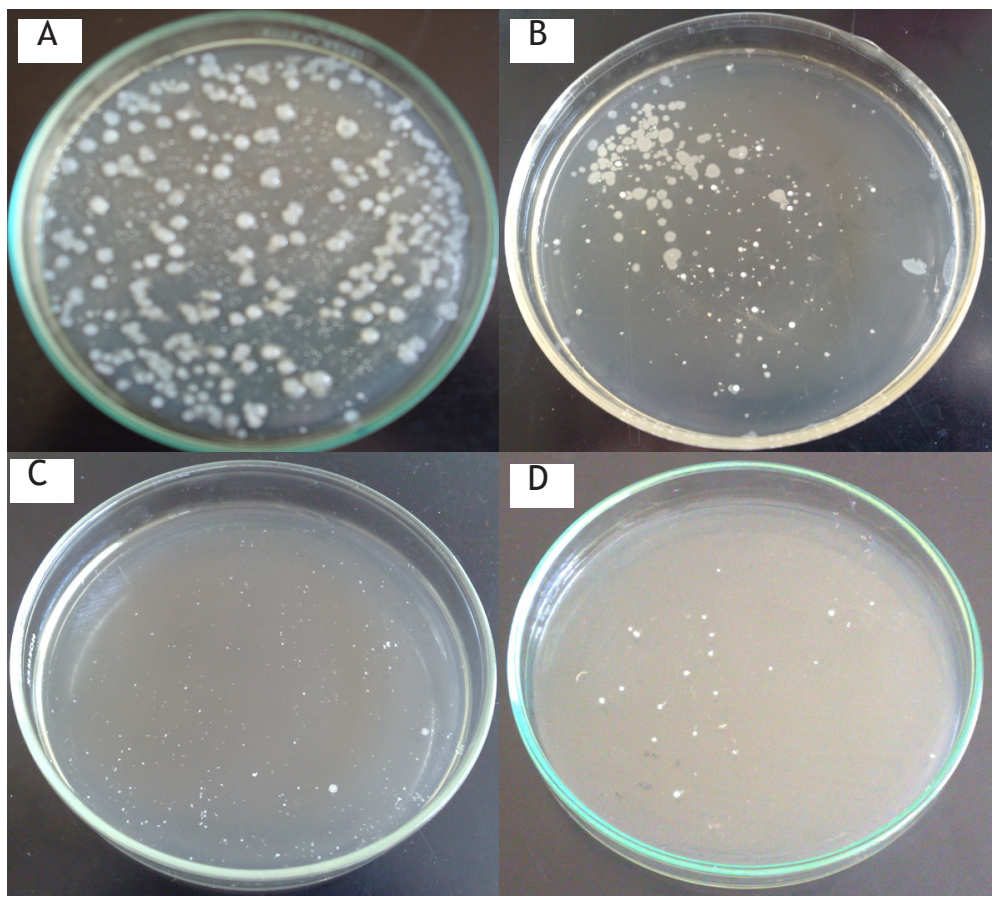

Figure 3. Plaque Isolate Streptococcus mutans growth; (A) Before Application of CPP-ACP paste, (B) After Application of CPPACP paste; (C) after CPP-ACP paste application topically in children teeth.

\section{DISCUSSION}

Based on Table 1 it showed decreased plaque isolate Streptococcus mutans colony growth amount after CPP-ACP paste application topically on children teeth, this could be caused by the mechanism of CPP-ACP that bonded with saliva pellicle. The bond between CPP-ACP and the pellicle of saliva inhibited the attachment of Streptococcus mutans and Streptococcus sobrinus. ${ }^{10}$

The pellicle mainly consisted of saliva glycoprotein which suited for bacterial attachment. ${ }^{17}$ Specific molecule on bacterial surface adhesins interact with the specific receptor of the pellicle thus it formed an attachment of bacteria to pellicle on teeth surface. Streptococcus mutans produced extracellular polysaccharide which is a glucan that being used for its attachment toward saliva pellicle of teeth surface. ${ }^{6}$ Carbohydrate particularly sucrose was cariogenic, which provide as a nutrition for microorganisms. ${ }^{18}$ Streptococcus mutans were acidogen plaque bacterias because it fermented carbohydrate and produced acids in large amount. The acid production decreased the plaque $\mathrm{pH}$ to a level where tooth demineralization occured and formed dental caries. While the plaque become acid, the ACP breakdown to free ions of calcium-phosphate thus acted as a reservoir for free ions of calcium-phosphate to maintain the calcium ion and phosphate ion saturation toward the enamel hydroxyapatite and the $\mathrm{pH}$ would also rapidly increased. The effect of CPP$A C P$ is to prevent the demineralization and induce the remineralization process. ${ }^{19}$

Demineralization is a dilution process of tooth enamel hydroxyapatite crystal, which mainly consisted of anorganic minerals such as calcium and phosphate, because of the reduced $\mathrm{pH}$ up to the critical $\mathrm{pH}(\mathrm{pH} 5)$ as a result of bacterial products of $\mathrm{acid}^{3,20}$, the tooth surface become porous and rough. This condition caused plaque accumulated more rapidly and retentive into the tooth surface thus harder to be cleaned, while a smooth tooth surface is harder for the bacterias to attach onto it. ${ }^{21-22}$

The amorph calcium and phosphate in CPP-ACP make it easier to diffuse into the tooth enamel and fill in the porosity from the surface to the inner part of the caries. From Oshiro et al..$^{23}$ study it was suggested that structural change of enamel and dentin surfaces to a more smooth in day-3, 14, and 28 after the application of CPP-ACP paste on the teeth. Based on this condition it was 
suggested that the CPP-ACP paste increased the tooth surface remineralization. Remineralization is a process of hyrdoxyapatite crystal reparation by placing the anorganic minerals on the tooth surface that lost those minerals. ${ }^{24}$

Based on Table 1, it showed that there was differences in Streptococcus mutans colony growth value in every subject, this could be caused by the consistency and flow of the saliva which differs between subjects. The Streptococcus mutans proliferated in the saliva pellicle in plaque formation mechanism. ${ }^{25} \mathrm{~A}$ viscous saliva is easier for glycoprotein to be attached on tooth surface and chance for bacterial attachment. Otherwise, an aqueous saliva will easily remove attached bacterias, because of the faster flow from a viscous saliva. ${ }^{26}$ Another concern is the chewing and swallowing mechanisms which will release microorganisms that was attached on the oral cavity surfaces. ${ }^{3}$

Based on the study, it showed that there were differences in Streptococcus mutans amount before and after CPP-ACP paste application topically on children teeth which reduced the Streptococcus mutans colony growth amount, so that the CPP-ACP paste can be an alternative for caries prevention.

It will be better for a dentist to choose a CPP-ACP paste to be used topically for 3 days, considering efficiency of time and cost. From the result of this study it showed that there were decreased values of dental plaque isolate Streptococcus mutans colony growth as much as 95\% after the CPP-ACP paste application topically on children teeth for 3 days, while in the period of 14 days it would be decreased $97.02 \%$ that means only $2.02 \%$ difference from both time period. On the tooth that was applied CPP-ACP paste, it showed structural change on the enamel and dentin surfaces to be smoother after 3 days of application. ${ }^{23}$

\section{CONCLUSION}

Based on this study, we concluded that there were differences in plaque isolate Streptococcus mutans growth amount before and after the CPP-ACP paste application topically on the children teeth which characterized by decreased
Streptococcus mutans growth amount after daily application of CPP-ACP paste for 1, 3, and 14 days.

\section{REFERENCES}

1. Wahyuni T. Sikat gigi bisa picu penyakit kronis. 2008. [cited 2008 Apr 7]. Available from: http; / / www. suarakarya-online.com/news. html?id=195313.

2. Tan HH. Kesehatan mulut. In: Houwink B. Ilmu kedokteran gigi pencegahan. Yogyakarta: Gajah Mada University Press; 1993. p. 275-7, 303-4.

3. Rosen S. Dental caries. In: Willet NP, White RR, Rosen S. Essential dental microbiology. London: Prentice-Hall Int. Inc.; 1991. p. 34551.

4. Perry DA. Plaque control for the periodontal patient. In: Newman MG, Takei HH, Klokkevold PR, Carranza FA. Clinical periodontology. $10^{\text {th }}$ ed. China: Saunders; 2006. p. 728-43.

5. Moyers RE. Handbook of orthodontics. London: Year Book Medical Publishers Inc.; 1988. p. 147-63.

6. Sanz M, Newman MG. Dental plaque and calculus. In: Nisengard RJ, Newman MG. Oral microbiology and immunology. $2^{\text {nd }}$ ed. Philadelphia: W.B. Saunders Co.; 1994. p. 32039.

7. Nuraini P, Tedjosasongko LI. Inisial akusisi Streptococcus mutans pada anak balita di Puskesmas Pucang Sewu Surabaya. J Penelitian Medika Eksakta 2003;4(3):196-202.

8. Marsh P, Martin MV. Oral microbiology. Oxford: Wright; 1999. p. 82-103.

9. Aimutis WR. Bioactive properties of milk proteins with particular focus on anticariogenesis. J Nutr 2004;134:989-95.

10. Schupbach P, Neeser JR. Golliard $M$, Rouvet M, Gugeinham B. Incorporation of caseionoglycomacropeptide and caseinophosphopeptide into the salivary pelicle inhibits adherence of Mutans Streptococci. J Dent Res 1996;75(10):1779-87.

11. Reynolds EC, Cai F, Shen P, Walker GD. Retention in plaque and remineralization of enamel lesions by various forms of calcium in mouthrinse or sugar-free chewing gum. J Dent Res 2003;82(3):206-11. 
12. Shen P, Cai F. Nowicki A. Vincent J, Reynolds EC. Remineralization of enamel subsurfaces lesions by sugar-free chewing gum containing casein phosphopeptide-amorphous calcium phosphate. J Dent Res 2001;80(12):2066-70.

13. Cai F, Shen P, Morgan MV, Reynolds EC. Remineralization of enamel subsurface lesions in situ by sugar-free lozenges containing casein phosphopeptide-amorphous calcium phosphate. Australian Dent J 2003;48(4):240-3.

14. Haake SK, Newman MG. Nisengard RJ, Sanz M. Periodontal microbiology. In: Newman MG, Takei HH, Carranza FA. Clinical periodontology. $9^{\text {th }}$ ed. Philadelphia: W.B. Saunders Co.; 2002. p. 96-112.

15. Babb JL, Hamada S. Microbiology of dental plaque. In: McGhee JR, Michalek SM, Cassel $\mathrm{GH}$. Dental microbiology. Philadelphia: Harper \& Row Publisher; 1982. p. 669-75.

16. Wan AKL, Seow WK, Walsh LJ, Bird PS. Comparison of five selective media for the growth and enumeration of Streptococcus mutans. Australian Dent J 2002;47(1):21-6.

17. Quirynen M, Teughels W, Haake SK, Newman MG. Periodontal microbiology. In: Newman MG, Takei HH, Klokkevold PR, Carranza FA. Clinical periodontology. $10^{\text {th }}$ ed. China: Saunders; 2006. p. 136-46.

18. Samaranayake LP, Jones BM, Scully C. Essential microbiology for dentistry. $2^{\text {nd }}$ ed. London: Churchil Livingstone; 2002. p. 267-81.
19. Reynolds EC. Anticariogenic complexes of amorphous calcium phosphate stabilized by casein phosphopeptide. A Review. 1998. [cited 2008 Mar 29] Available from: http://www. recaldent.com/images/anticarc.pdf.

20. Wollinsky LE. Caries and cariology. In: Nisengard RJ, Newman MG. Oral microbiology and Immunology. $2^{\text {nd }}$ ed. Philadelphia: W.B. Saunders Co.; 1994. p. 341-4.

21. Wilkins EM. Clinical practice of the dental hygienist. Philadelphia: Lippincott Williams \& Wilkins; 1999. p. 264-76.

22. Bagg J, MacFarlane TW, Poxon IR, Miler $\mathrm{CH}$, Smith AJ. Essentials of microbiology for dental students. New York: Oxford University Press; 2003. p. 233, 238-9.

23. Oshiro M, Yamaguchi T, Takamizawa $\mathrm{H}$, Inage T, Watanabe A, Irokawa S, et al. Effect of CPPACP paste on tooth mineralization an FE-SEM study. J Oral Sci 2007;49(2):115-20.

24. Kidd EAM, Bechal SJ. Dasar-dasar karies. Jakarta: EGC; 1991. p. 30-1.

25. Michalek SM, MCGhee JR. Oral streptococci with emphasis on Streptococcus mutans. In: McGhee JR, Michalek SM, Cassel GH. Dental microbiology. Philadelphia: Harper \& Row Publisher; 1982. p. 678-90.

26. Veld HJH, Helderman WHVP. Driks OB. Plak gigi. In: Houwink B. Ilmu kedokteran gigi pencegahan. Yogyakarta: Gajah Mada University Press; 1993. p. 58-61, 75-83. 